\title{
Peacekeeping Doctrine: An Autonomous Legal Order?
}

\author{
Nigel D. White*
}

\begin{abstract}
This article explores the legal bases of autonomy in peacekeeping and whether it has developed to such an extent that there are signs of a self-referential legal order governing peacekeeping, separate from other legal orders. Given that it will be shown that the principles governing peacekeeping are derived from general international law, there must be a presumption against there being a self-referential legal order, but the possibility that there has been a significant development of specific principles and rules will be explored. Moreover, this development may have occurred to such an extent that although the original source may remain in international law, a separate legal order has emerged. If the norms of that legal order no longer reflect the wider principles of international law then concerns revolve not only around fragmentation of international law, but also around the continuing compatibility of peacekeeping with international law.
\end{abstract}

\section{Key words}

Peacekeeping, autonomy, doctrine, international law

\section{Peacekeeping and Autonomy}

\footnotetext{
* Professor of Public International Law, The University of Nottingham, UK
} 
Although it does not have a monopoly over peacekeeping, either legally or practically, the $\mathrm{UN}$ is its leading proponent and practitioner. ${ }^{1}$ It is also responsible for developing a doctrine of peacekeeping, in the sense of a body of principles that govern the definition, creation and operation of peacekeeping. According to UN doctrine:

Peacekeeping is a technique designed to preserve the peace, however fragile, where fighting has been halted, and to assist in implementing agreements achieved by the peacemakers. Over the years, peacekeeping has evolved from a primarily military model of observing cease-fires and the separation of forces after inter-state wars, to incorporate a complex model of many elements - military, police and civilian working together to help lay the foundations for sustainable peace. ${ }^{2}$

The nature of peacekeeping means that it has to be autonomous in the sense of being separate from member states in order to be fulfil its functions when deployed between states (interstate peacekeeping) or between factions within states (intra-state peacekeeping). Peacekeeping depends on its independent status to ensure that it has the consent and cooperation of the parties, whether states or non-state actors, and to ensure that peacekeepers are protected persons against whom attacks are prohibited. ${ }^{3}$ Peacekeepers embody the values of UN, or other organisations such as the EU or AU, and are more broadly seen as representing the international community. ${ }^{4}$

Moreover, as Collins has written "legal autonomy implies some degree of institutional autonomy", 5 meaning that, in the case of international law institutions are important in separating law from politics, and demonstrate that international law is not simply the political practice of states. Institutions in the shape of inter-governmental organisations may not systematically achieve this because their political organs do not always have sufficient

\footnotetext{
${ }^{1}$ J.A. Koops, N. Macqueen, T. Tardy and P.D. Williams (eds.), The Oxford Handbook of United Nations Peacekeeping Operations (Oxford University Press, Oxford, 2015) p.1.

2 'United Nations Peacekeeping Operations: Principles and Guidelines' (UNDPKO, New York, 2008) p.17.

${ }^{3}$ Article 7, Convention on the Safety of United Nations and Associated Personnel 1994.

${ }^{4}$ The UN's 1990 Model Status of Forces Agreement (SOFA) states at para. 6 that: "The United Nations peacekeeping operation and its members shall refrain from any activity incompatible with the impartial and international nature of their duties or inconsistent with the spirit of the present arrangements", in UN Doc A/45/594 (1990). On the EU's 2003 SOFA see A. Sari, 'The European Union Status of Forces Agreement (EU SOFA)', 13 Journal of Conflict and Security Law (2008) p.353.

${ }^{5}$ R. Collins, 'Modernist-Positivism and the Problem of Institutional Autonomy', in R. Collins and N.D. White (eds.), International Organizations and the Idea of Autonomy: Institutional Independence in the International Legal Order (Routledge, London, 2011) p.25.
} 
separation from states, but in some areas organisations have collectively shaped new areas of law out of functional necessity in order to achieve their aims and objectives. In some areas it is organisations rather than states that have shaped a particular area of practice and, moreover, the norms that regulate it, through articulation of principles of peacekeeping and the duties and rights of peacekeepers. The UN can stake a claim for exercising both legal and institutional autonomy in the area of peacekeeping, despite its dependency on member states to operationalise it.

In order to craft an area of practice and law, such as peacekeeping, there has to be a legal separation of the UN or any other relevant organisation from member states. The UN is legally autonomous in the sense of having international legal personality and having express and implied powers, but this does not solve the practical problem of dependency on member states, which is particularly acute in case of UN peacekeeping where the doctrine of UN command and control contrasts with the presence and intrusion of the national concerns of troop contributing nations (TCNs). Apart from elements of supranationality especially when the Security Council is exercising powers under Chapter VII of the UN Charter, the UN is in most respects an inter-governmental organisation and, therefore, the layers of autonomy within which peacekeeping might be located can be quite thin. In contrast, the EU is commonly characterised as a supranational organisation with concomitant autonomy, but less so in the field of security and defence, where the EU is faced with the same issues of dependency and, moreover, in peacekeeping at least often plays a secondary role to the UN. ${ }^{6}$

The presumption in this contribution is that 'autonomy' is an explanatory tool, a way of understanding the legal regime applicable to peacekeeping, not as a term readily used by organisations in the context of peacekeeping. However, this presumption may be rebutted, though the evidence is that 'independence' is the term used to encapsulate much of what is embodied in the discussion of autonomy. The purpose of this article is to explore the legal bases of autonomy in peacekeeping and the limits upon it, but also whether it has developed to such an extent that there are signs of a self-referential legal order governing peacekeeping, separate from other legal orders. Given that it will be shown that the principles governing peacekeeping are derived from general international law, there must be a presumption against

\footnotetext{
${ }^{6}$ M. Brosig, 'EU Peacekeeping in Africa: From Functional Niches to Interlocking Security', 21 International Peacekeeping (2014) p.74; N. Tsagourias, 'EU Peacekeeping Operations: Legal and Theoretical Issues', in M. Trybus and N.D. White (eds.), European Security Law (Oxford University Press, Oxford, OUP, 2007) p.102.
} 
there being a self-referential legal order, but the possibility that there has been a significant development of specific principles and rules will be explored. Moreover, this development may have occurred to such an extent that although the original source may remain in international law, a separate legal order has emerged. If the norms of that legal order no longer reflect the wider principles of international law, then concerns revolve not only around fragmentation of international law, ${ }^{7}$ but also around the continuing compatibility of peacekeeping with international law.

The fact that the principles governing peacekeeping were so clearly derived from general international law in 1956 upon the establishment of the first UN peacekeeping force, addresses the main concern about fragmentation expressed by the International Law Commission's Study Group on fragmentation- that it involves the "rise of specialized rules and rule-systems that have no clear relationship to each other". 8 Indeed, the relationship between the peacekeeping regime and general international law fits the ILC Study Group's hypothesis that international law co-ordinates and organizes the cooperation of "(autonomous) rule-complexes and institutions". 9 Furthermore, it is "general international law that provides the rudiments of an international public realm from the perspective of which the specialized pursuits and technical operations carried out under specific treatyregimes may be evaluated". ${ }^{10}$ In other words, the legal regime governing peacekeeping, shaped by the UN must conform to general international law shaped by all states. However, with the UN there is the added complexity of Chapter VII of the Charter, which grants the Security Council exceptional powers to override basic principles of sovereignty and consent in order to restore international peace and security and, moreover, Article 103 of the Charter provides that if obligations arising from Security Council measures conflict with the exiting treaty obligations of states, the duties of the Charter including those arising by means of Security Council resolutions, prevail. Thus, while it is true to say that generally speaking the specialist rule-making found in peacekeeping is the implementation of general and indeterminate standards of international law at a specific level, ${ }^{11}$ there is the possibility of the

\footnotetext{
${ }^{7}$ Report of the Study Group of the International Law Commission, finalized by Martii Koskenniemi, 'Fragmentation of International Law: Difficulties Arising from the Diversification and Expansion of International Law', UN Doc A/CN.4/L.682 (2006).

${ }^{8}$ Ibid, p. 245 .

${ }^{9}$ Ibid, p.247.

${ }^{10}$ Ibid, p. 255

${ }^{11}$ Ibid, p.255.
} 
Security Council driving peacekeeping beyond that into an autonomous, self-referential legal order.

\section{Layers of Autonomy in Organisations}

The autonomy of organisations embodied in the notion of international legal personality explains the legal separation of an organisation from member states, but it tells us little about whether there is an autonomous legal order governing peacekeeping, separate from other legal orders such as general international law or the national laws of states contributing troops to peacekeeping forces (TCNs). Legal personality is seen in doctrinal analyses as the foundation upon which organisations exercise legal powers, including the flexible doctrine of implied powers, ${ }^{12}$ which is not only the source of UN peacekeeping but it is also the foundation upon which separate legal orders emerge such as the legal regime governing peacekeeping.

Furthermore, there is the possibility that the peacekeeping regimes of separate organisations may converge to become an overarching autonomous legal order, a specialist area of international law, particularly when organisations such as the UN, EU and AU work closely together in creating and controlling peacekeeping forces. The primacy of the UN in peacekeeping matters, however, remains evident. In 2014, the President of the UN Security Council, in a statement on cooperation between the UN and regional and subregional organisations in maintaining peace and security, emphasised the purposes and principles of the UN Charter, its primary responsibility for peace and security, the applicability of Chapter VIII of the UN Charter, then stressed the importance for the UN of developing the AU's ability to deploy peacekeeping forces rapidly in support of UN peacekeeping operations, and welcomed the support given by the EU to the AU to operationalise the African Standby Force. ${ }^{13}$ A resolution on the role of the EU within the UN, adopted by the European Parliament in 2015, emphasised the EU's "full compliance" with the provisions of the UN Charter, its "crucial role in promoting the principles and goals of the UN", but also noted its "special responsibility for peacekeeping development and human rights where its

\footnotetext{
${ }^{12}$ H.G. Schermers and N.M. Blokker, International Institutional Law (Martinus Nijhoff, Leiden, 2011) p.188.

${ }^{13}$ UN Doc S/PRST/2014/27, 16 December 2014.
} 
neighbourhood is concerned" ${ }^{14}$ In a review of practice in both UN and non-UN peace operations, Bellamy and Williams state that "despite the proliferation of peacekeeping actors, the UN has retained its dominant position". Furthermore, "not only does the UN remain the world's primary peacekeeper by a considerable margin, there is evidence that the Security Council's authority as a source of peacekeeping mandates has strengthened with time". ${ }^{15}$

Debate about legal autonomy of organisations normally revolves around the concept of international legal personality and the powers that flow from it. Two pivotal International Court of Justice cases of 1949 and 1962 consolidate the ideas of personality and implied powers and thereby autonomy in that sense of separate legal existence and powers from states. However, they do not establish fully the idea of an autonomous legal order as has occurred in the EU, largely through the jurisprudence of the European Court of Justice. Autonomy in that sense has not been created by the principal judicial organ of the UN, although its opinions of 1949 and 1962 create the foundations for this. In the Reparations opinion of 1949, the Court spoke about "the progressive increase in the collective activities of States" giving "rise to instances of actions upon the international plane by certain entities which are not States", culminating in the creation of the UN, "whose purposes and principles are specified in the Charter" - "but to achieve these ends the attribution of international personality is indispensable". ${ }^{16}$ In the Expenses opinion of 1962, which was concerned with the financing of peacekeeping, the Court was of the view that the purposes of the UN were broad with "primary place ascribed to international peace and security". Although states retained their "freedom of action" save where they had entrusted the UN with the attainment of "common ends", the Court concluded that when the UN "takes action which warrants the assertion that it was appropriate for the fulfilment of one of the stated purposes of the United Nations, the presumption is that such action is not ultra vires the Organization". ${ }^{17}$

The earlier opinion recognises the $\mathrm{UN}$ as a separate legal entity, while the later case recognises that its broad purposes will necessitate an expansion in autonomy. In the case of UN peacekeeping, layers of autonomy have been added to the core concept of personality and powers, especially with the exercise of legislative and executive competence by its political

\footnotetext{
${ }^{14}$ OJ, No. 2017/C 366/05, 24 November 2015.

15 A.J. Bellamy and P.D. Williams, 'Trends in Peace Operations, 1947-2013', in Koops, Macqueen, Tardy and Williams, supra note 1, p.19.

${ }^{16}$ Reparation for Injuries Suffered in the Service of the United Nations, 1949 ICJ, Advisory Opinion, p.178.

${ }^{17}$ Certain Expenses of the United Nations, 1962 ICJ, Advisory Opinion, p.168.
} 
organs. ${ }^{18}$ It is largely in the latter layer that UN peacekeeping sits, as a product of the executive (and sometimes governing and legislative) powers of the Security Council under Article 24 (which gives it primary responsibility for peace and security), and Chapters VI and VII, which grant it competence over the peaceful settlement of disputes and the ability to take action to combat threats to or breaches of the peace respectively. Schermers and Blokker categorise the Security Council as a "governing board", with its own broadly drawn functions and powers, independent of the plenary organ (the General Assembly) and, therefore, more autonomous than an "executive board", which simply executes the decisions of the plenary organs. ${ }^{19}$

Peacekeeping has also grown from the executive (as well as administrative powers) of the UN Secretary General under Articles 98 and 99. Under the latter provision, the Secretary General has the express power to bring threats to the attention of the Security Council and had developed implied powers from this to carry out diplomatic initiatives and launch inquiries. Furthermore, under Article 98 he has delegated executive competence from the Security Council (or General Assembly) to establish and command peacekeeping operations. In a way, peacekeeping was initially created in 1956 by a legislative act of the General Assembly which, in the face of a deadlocked Security Council and on the initiative of the UN Secretary General Dag Hammarskjold, established a United Nations Command for a UN Emergency Force (UNEF) to secure and supervise the cessation of hostilities in the Middle East. It also appointed a Chief of the Command who was authorized to recruit to the force, and invited the Secretary General "to take such administrative measures as may be necessary for the prompt execution of the actions envisaged in the present resolution". ${ }^{20}$

In other organisations, peacekeeping is a product of decisions by the political organs, exercising executive and other powers. The peacekeeping tasks of the EU find expression within its Common Security and Defence Policy (CSDP), originating in the St Malo Declaration of 1998, and listed in Article 43(1) of the Treaty on European Union (TEU). Peacekeeping is activated by a decision of the Council, and is run politically by the Political and Security Committee established by Article 38 TEU, and militarily by the European

\footnotetext{
${ }^{18}$ N.D. White, 'Layers of Autonomy in the UN System', in Collins and White, supra note 5, p.298. See further D. Curtin and I. Dekker, 'The EU as a "Layered International Organisation: Institutional Unity in Disguise', in P. Craig and G. de Burca (eds.), The Evolution of EU Law (Oxford University Press, Oxford, 1999) p.83.

${ }^{19}$ Schermers and Blokker, supra note 12, pp.302-4.

${ }^{20}$ UN Doc A/RES/1000 (ES-I, 1956).
} 
Military Committee established by the Council. ${ }^{21}$ More broadly Koutrakos states that the 'deep institutionalization of the CSDP and the development of the culture of cooperation between its administrative bodies comprising national officials highlight the organizational autonomy of the policy'. ${ }^{22}$ Nevertheless, with peacekeeping and peace operations generally, the development is in fact due to a combination of institutional policy and lawmaking, combined with contributions, consent, and cooperation by member states. ${ }^{23}$ States possess military capability, while organisations do not as yet. The UN depends upon standbyagreements with member states in order to staff a peacekeeping force, agreements that give member states the final say as to whether to contribute troop contingents. ${ }^{24}$

There has been limited integration of military forces within parts of EU membership, but not across the membership in whole or in significant part. ${ }^{25}$ In the African Union, peacekeeping is based on Article 4(j) of the Constitutive Act of the AU of 2000, namely "the right of Member States to request intervention from the Union in order to restore peace and security". The authorisation for such forces comes from an executive body, the AU Peace and Security Council (PSC), established by a separate protocol. ${ }^{26}$ Again while the development and authority come from the institution, military contributions are from member states, although there is provision for an African Standby Force, which would be available for intervention in the face of grave crimes but also for consensual peacekeeping, ${ }^{27}$ progress towards the creation of which has been slow. ${ }^{28}$

While these provisions establish the autonomy of EU and AU peacekeeping, both organisations have a subsidiary relationship to the UN. The EU's peacekeeping operations have been exclusively outside the EU's membership and region, in Macedonia in 2003, the

\footnotetext{
${ }^{21}$ Council Dec. 2001/79/CFSP [2001] OJ L 27/4. See also the Military Staff of the European Union, established as part of the Secretariat of the Council - Council Dec. 2001/80/CFSP [2001] OJ L 27/7.

${ }_{22}$ P. Koutrakos, The EU Common Security and Defence Policy (Oxford University Press, Oxford, 2013 ) p.67.

${ }^{23}$ M.H.A. Larive, Debating European Security and Defense Policy (Routledge, London, 2014), ch. 9; S. Biscop and J. Coelmont, 'Military CSDP: the Quest for Capability', in S. Biscop and R.G. Whitman (eds.), The Routledge Handbook of European Security (Routledge, London, 2013) p.78.

${ }^{24}$ D.J. Scheffer, 'United Nations Peace Operations and Prospects for a Standby Force', 28 Cornell International Law Journal (1995) p.649.

${ }^{25}$ M. Trybus, 'The Vision of the European Defence Community and a Common Defence for the European Union', in Trybus and White, supra note 6, p.13.

${ }^{26}$ Protocol Relating to the Establishment of the Peace and Security Council of the African Union 2002, Article 6 of which lists its functions including the creation of " $\mathrm{d}$. peace support operations and intervention, pursuant to article 4(h) and (j) of the Constitutive Act".

${ }^{27}$ Ibid, Article 13(3)(d).

${ }^{28}$ E. de Volder, Towards Achieving Pax Africana? The AU's Comprehensive and Multi-layered Collective Security System (Intersentia, Antwerp, 2018) pp.135-41.
} 
DR Congo in 2003 and again in 2006, Bosnia from 2004, Chad and the Central African Republic (CAR) in 2008-9, and the CAR in 2014-15, requiring the authorisation of the Security Council for that reason, with a number of these forces operating in support of UN peacekeeping forces. ${ }^{29} \mathrm{AU}$ operations, on the other hand, have been exclusively within its membership and region, in Burundi in 2003, Darfur from 2004, Comoros in 2006, Somalia from 2007, and CAR from 2013, some of which have been hybrid UN-AU operations authorised by the Security Council. ${ }^{30}$ While there is no doubt that the autonomous European and African legal orders allow for the deployment of peacekeeping forces within their respective regions, ${ }^{31}$ only the $\mathrm{UN}$, through the Security Council, has the universal competence to mandate such forces outside these regions and, as the above practice shows, there is often a need for a UN mandate and material support within the region as well. As de Volder argues in the case of the AU, "this hierarchical 'partnership' has prompted cooperation, but at the same time has led to controversies in the working relationship between" the UN and AU. ${ }^{32}$

In the case of the UN, peacekeeping exploits the space between Chapters VI and VII of the UN Charter, building on the benign and non-threatening UNEF model crafted in 1956 during the Suez Crisis, when the UN force was, on the one hand, based on traditional principles of international law but, on the other, was institutionally (and therefore legally) separate from member states. In his initial report on the establishment of the first peacekeeping (or "emergency international force") in 1956, Secretary General Hammarskjold emphasised that the first step would be to establish the separateness of UN Command over a force where neither the commanders not the troops would be drawn from permanent members. ${ }^{33}$ In his second report on UNEF under the heading "questions of principle", the Secretary General pointed out that the model adopted for the first force was an application of the principles of the UN Charter, reflected in the separate commander whose "authority should be so defined as to make him fully independent from any one nation" and who reported to the Secretary General. ${ }^{34}$ This contrasted the delegation of authority and command to the US six years earlier in the Korean War, the first example of peace enforcement authorised by the UN

\footnotetext{
${ }^{29}$ See, for example, UN Doc S/RES/1575 (2004) re EUFOR in Bosnia.

${ }^{30}$ See, for example, UN Doc S/RES/1769 (2007) re AU/UN hybrid operation in Darfur (UNAMID). See also UN Doc S/RES/1744 (2007) re the AU Mission in Somalia (AMISOM).

${ }^{31}$ J.A. Koops and T. Tardy, 'UN Inter-Organizational Relations in Peacekeeping', in Koops, Macqueen, Tardy, Williams, supra note 1, p.63.

${ }^{32}$ de Volder, supra note 28, p.78.

${ }^{33}$ UN Doc A/3289 (1956) pp.1-3.

${ }^{34}$ UN Doc A/3302 (1956) p.2.
} 
Security Council under Chapter VII. ${ }^{35}$ The Secretary General did not rule out the Security Council using peacekeeping forces "within the wider margins provided under Chapter VII", ${ }^{36}$ but this issue did not arise given that UNEF was mandated by the General Assembly in the face of opposition by France and the UK in the Security Council. That meant that UNEF was based on clear principles of international law, respecting sovereignty (in the form of consent both to the presence of the force and to contributions to it) and non-aggression (on the basis that it could not enforce a peace), which seemingly restricted the autonomy of peacekeeping. ${ }^{37}$ However, peacekeeping was crafted as a consensual form of intervention against a background of a rejection of more coercive military forms of intervention, and its benign birth should be contrasted with the more belligerent progeny that came later. There was a more practical restriction on the basis that while the command of the operation was clearly with the UN, the necessity of setting up the force in short order, meant that "countries participating in the Force should provide self-contained units", 38 thereby eroding (or balancing) the UN's autonomy in peacekeeping.

It can be seen in these brief reports on UNEF, in which the Secretary General articulates the principles of peacekeeping, how he is using his powers under Articles 98-99 to craft a form of military operation that exploits the spaces between national sovereignty and international authority, between Chapter VI and VII of the UN Charter and, moreover, between the traditional norms of international law of sovereignty and non-aggression on the one hand and intervention by invitation on the other. Moreover, the entirely new concept of peacekeeping meant that autonomy could be extended in the application and development of the principles of peacekeeping by subsequent practice. Each iteration of peacekeeping has added new layers of autonomy: from the Congo force of the 1960s; the multidimensional operations of the early 1990s, where peacekeeping was combined with election monitoring; the administrative models of Kosovo and East Timor in 1999; to the current Force Implementation Brigade in the Congo.

\section{Elements of Autonomy}

\footnotetext{
${ }^{35}$ Ibid.

${ }^{36}$ Ibid, p.4.

${ }^{37}$ Ibid, pp.4-5.

${ }^{38}$ Ibid, p.6.
} 
The UN, EU, AU and other organisations possessing international legal personality are legally autonomous from member states, but they still remain dependent upon member states to achieve their tasks, especially military ones where troops have to be drawn from TCNs, and thereby bringing with them national security concerns into what is intended to be an exercise in collective security. This might seem to make it more difficult to claim autonomy in peacekeeping and other military operations than in other areas of institutional activity, which are not so dependent upon the capabilities of states. For example, international organisations can impose sanctions upon other states without positively calling on the resources of member states, but the reality is that organisations still depend on states to enforce those sanctions. Perhaps a better example would be in the actions of the specialized agencies, or programmes such as the UNHCR, who have their own resources that can be put into place in times of emergency, without the need to call on states' resources. However, even in military operations, close to the heart of the sovereignty of states, there is evidence of autonomy more so in peacekeeping than peace enforcement operations.

In general terms, the above analysis revealed two key elements of autonomy in peacekeeping: first the legal independence of the organisation and its peacekeeping missions from member states; and secondly, evidence of a self-referential peacekeeping legal order, independent from international law and national law. The second element flows from the first in that legal personality creates an autonomous space between organization and member states, which is consolidated by the creation of peacekeeping forces that are at least in part creations of the organisation. Those political organs responsible for their creations enclose them in a legal framework, largely to prevent them from too powerful. ${ }^{39}$ Of course there remains the possibility that such forces may become more powerful, and the peacekeeping regime is stretched to allow for wider and wider action reflected in peacekeeping law that departs significantly from general international law. The advantage of autonomy in the shape of a self-referential legal order is that it is a specialist area of law developed to regulate specific activities, in contrast to the application of abstract and arguably indeterminate principles of international law such as non-intervention. ${ }^{40}$ The disadvantage of autonomy is that peacekeeping may become isolated from broader community norms, which all states have signed up to.

39 A. Guzman, 'International Organizations and the Frankenstein Problem', 24 European Journal of International Law (2013) p.1000.

${ }^{40}$ M. Jamnejad and M. Wood, 'The Principle of Non-Intervention', 22 Leiden Journal of International Law (2009) p.345. 


\subsection{Legal Independence of Peacekeeping}

\subsubsection{The Power to Create}

Without going into a detailed and formalist textual analysis of Articles 36, 40 or 14 of the UN Charter, ${ }^{41}$ in general terms the creation of peacekeeping required significant constitutional development of the Charter by Dag Hammarskjold, relying on the purposes and principles of the UN and the fact that peacekeeping does not violate any express prohibition of the Charter. If the UN Security Council can mandate military enforcement action it can mandate a more consensual form of military operation, and, if that operation is based on consent of the host states or states, then this can come within the UN General Assembly's recommendatory powers on peace and security.

The ICJ in the Expenses case analysed specific articles in its quest to find a legal basis, but rather with a view to determining the limitations on the General Assembly's competence. ${ }^{42}$ The Court comes close to a doctrine of inherent powers, ${ }^{43}$ although it does not use the term "powers" to any great extent. A wide view of implied powers linked to the purposes of the $\mathrm{UN}$ is the more orthodox way of analysing the approach taken by the Court in the Expenses case, ${ }^{44}$ but that is a long way from the idea of implied powers being derived from the intent of the founding states. As has been seen, the idea of international organisations having competence to create peacekeeping operations was considered to be mainstream by the time of the creation of the EU's CSDP first recognised in 1998, and in the shape of the AU's Constitutive Act in 2000 and its Security Protocol in 2002, in which peacekeeping is expressly included.

Despite the rhetoric of subjectivity attached to implied powers, in reality an objective approach is taken to the competence to establish and maintain peacekeeping forces rather than a subjective one, meaning that the autonomy of peacekeeping is neither derivative nor in

\footnotetext{
${ }^{41}$ A. Orakhelashivili, Collective Security Law (Oxford University Press, Oxford, 2011) ch 8.

${ }^{42}$ In Articles 11(2) and 12 of the UN Charter 1945.

43 As cogently argued before the Court delivered its opinion by F. Seyersted, 'UN Forces: Some Legal Problems', 37 British Yearbook of International Law (1961) p.351.

${ }^{44}$ Schermers and Blokker, supra note 12, p.182.
} 
the hands of member states, but in the very nature of an organisation having the purpose of achieving peace and security. In the case of the EU, although peace is not seen as prominent, it can be seen as the primary reason for the creation of the European Economic Community in the Treaty of Rome 1957, which stated in its preamble that the founding states were "resolved to strengthen the safeguards of peace and liberty by establishing this combination of resources". In the case of the AU, peace and security is more prominent in the purposes one of which is to "promote peace, security, and stability on the continent", 45 while the UN's primary purpose is depicted as being the achievement of international peace and security. ${ }^{46}$ This is supported by the range of powers granted in the UN Charter to the most powerful organ, the Security Council, which are exclusively concerned with peace and security. ${ }^{47}$ The plenary organ's powers are also largely designed to create a normative framework to achieve peace and security, although this framework also includes socio-economic matters and human rights. $^{48}$

The UN's competence to create peacekeeping forces ceased to be controversial after the dust had settled following the Expenses case in 1962; though there was no real hiatus as evidenced by the creation of the UN Force in Cyprus in $1964 .{ }^{49}$ The modern day acceptance of peacekeeping should not disguise the pioneering nature of its creation in 1956, requiring powers additional to the ones expressly granted to the UN in 1945. The extension of UN peacekeeping to an intra-state situation in the Congo in $1960,{ }^{50}$ which dragged the UN force into fighting non-state armed groups that threatened the newly independent state's territorial integrity, added to the sense of a voyage into the unknown, in that the benign non-threatening version of peacekeeping crafted in 1956 now had a more belligerent and dangerous counterpart. While this violent version lay dormant for the remainder of the Cold War, allowing for a legal order to be crafted around the UNEF model of 1956, it was re-awoken in Somalia in $1993,{ }^{51}$ and on a number of occasions thereafter. This set the UN on a path towards crafting an autonomous legal order to govern both versions of peacekeeping that was acceptable to the membership. While the universal consensus around benign peacekeeping was readily transferable to regional organisations embodied in the express grants of such

\footnotetext{
${ }^{45}$ Article 3(j) Constitutive Act of the AU 2000.

${ }^{46}$ Articles 1(1) and 24(1) UN Charter 1945.

${ }^{47}$ Articles 33-42 UN Charter 1945.

${ }^{48}$ Articles 11(1) and 13 UN Charter 1945.

${ }^{49}$ UN Doc S/RES/186 (1964).

${ }^{50} \mathrm{UN}$ Doc S/RES/143 (1960).

${ }^{51}$ UN Doc S/RES/814 (1993).
} 
competence, there remains controversy over the extent to which regional organisations have an autonomous competence to deploy belligerent peacekeeping forces. ${ }^{52}$ In a sense there is an on-going debate about the extent to which peacekeeping can be stretched beyond a consensual non-violent model based on classical principles of international law.

\subsubsection{Operations as Organs}

Furthermore, the UN sees peacekeeping forces as legally autonomous from states in the form of being subsidiary organs of the UN, either created by the Security Council or the General Assembly under Charter provisions that allow for the creation of such organs. ${ }^{53}$ The existence of a separate peacekeeping budget, based on the UN's scale of assessments, reinforces the idea that this is a collective effort, unlike the decentralised enforcement model used, for example in Iraq in 1991, in which the contributing states do not operate under UN command and control, the operation is not viewed as a subsidiary organ, and members of the coalition pay for their own contributions to the operation. Within the EU, the financing of military operations is an exception to the general rule that CSDP activities are paid out of the Union budget, expenditure is charged to member states in accordance with the Gross National Product Scale, unless a state has abstained in the Council vote establishing the operation. ${ }^{54}$ However, there is no indication that the EU views peacekeeping operations as anything more than a collection of state organs, although there is EU command and control. ${ }^{55}$ In the AU, there is provision for collective funding in the form of a Peace Fund in the 2002 Protocol. ${ }^{56}$ The African Standby Force, when established, would be centrally commanded and controlled and would be presumably viewed as a subsidiary organ of the AU but, pending the establishment of this force, the model used is one of coalitions of the willing, whereby contributing states "bear their own cost and are under the leadership of one nation". 57

\footnotetext{
${ }^{52}$ E.P.J. Myjer and N.D. White, 'Peace Operations Conducted by Regional Organizations and Arrangements', in T. Gill and D. Fleck (eds.), The Handbook of the International Law of Military Operations (Oxford University Press, Oxford, 2015) p.185.

53 Articles 22 and 29 UN Charter 1945. See, for example, statement by the UN Secretariat that a "UN peacekeeping force established by the Security Council or the General Assembly is a subsidiary organ of the UN" - UN Doc A/CN.4/545 (2004), para 17.

${ }^{54}$ Article 41 Treaty on European Union.

${ }^{55}$ Koutrakos, supra note 22, p.103, p.127.

${ }^{56}$ Article 21, Protocol, supra note 26.

${ }^{57}$ de Volder, supra note 28, pp.139-40
} 
In the field of peacekeeping the UN exhibits the greatest autonomy and this is further reflected in the fact that the UN historically has accepted responsibility for the wrongful acts of its peacekeeping forces as subsidiary organs. ${ }^{58}$ However, under the ILC's Articles on the Responsibility of International Organisations of 2011, and in some domestic judicial decisions, ${ }^{59}$ a factual test of "effective control of conduct" is preferred to a legal test of "ultimate authority and control", 60 potentially undermining a positive aspect of UN peacekeeping in the form of the organisation's willingness to accept responsibility for the actions of its peacekeepers.

The debate about the applicable rules in the ILC's Articles on the Responsibility of International Organisations 2011 revolves around the question whether for the purposes of attribution of wrongful conduct of peacekeepers the rule in Article 6 or the rule in Article 7 applies. ${ }^{61}$ Article 6 states that "the conduct of an organ or agent of an international organization in the performance of function of that organ or agent shall be considered an act of that organization", while Article 7 states that the "conduct of an organ of a State ... that is placed at the disposal of" an international organisation shall be considered an act of the organisation if it "exercises effective control over that conduct". Given that a peacekeeping force is both a UN subsidiary organ (as recognised by the UN) and a collection of organs of states (in the form of contingents from TCNs) then, in theory, either or both Articles are applicable. However, the ILC in its commentary views issues of attribution of conduct in peacekeeping operations as coming within the test under Article 7 rather than Article $6 .{ }^{62}$ That position does not extinguish UN responsibility even when it does not exercise such a high degree of control if the UN continues to accept it. ${ }^{63}$ The gradual emergence of the UN from behind its shield of immunity in Haiti, ${ }^{64}$ but only in the sense of accepting moral rather than legal responsibility for the lethal outbreak of cholera due to the negligence of its

\footnotetext{
${ }^{58}$ UN Secretariat - "as a subsidiary organ of the United Nations, an act of a peacekeeping force is, in principle, imputable to the Organization, and if committed in violation of an international obligation entails the international responsibility of the Organization and its liability in compensation" - UN Doc A/CN.4/545 (2004), para 17.

${ }^{59}$ P. Palchetti, 'Attributing the Conduct of Dutchbat in Srebrenica: the 2014 Judgment of the District Court in the Mothers of Srebrenica Case', 62 Netherlands International Law Review (2015) p. 279.

${ }^{60}$ Agin Behrami and Bekir Behrami v. France (Application no. 71412/01) para.140.

${ }^{61}$ UN Doc A/CN.4/L.778 (2011).

${ }^{62}$ ILC Report of the Work of the Sixty-Third Session, UN Doc A/66/10 (2011), 87-8.

${ }^{63}$ B. Oswald, H. Durham and A. Bates (eds), Documents on the Laws of UN Peace Operations (Oxford, Oxford University Press, 2010) p.324.

${ }^{64}$ As provided in section 2 of the Convention on the Privileges and Immunities of the United Nations 1946.
} 
peacekeepers in $2010,{ }^{65}$ is an acid test as regards the UN's status as an independent moral and legal actor.

Immunity from the jurisdiction of local courts is potentially a negative aspect of autonomy although its rationale is to protect the UN's independence from interference by member states. On the other hand, accountability is a positive aspect and its presence would show a growing confidence in the robustness of the UN's legal order, in the sense that the order has not only generated norms of conduct for peacekeeping operations and peacekeepers, but that compliance and accountability mechanisms are also developing. A developed legal order should contain both primary rules and secondary means to ensure compliance, and accountability for violation. ${ }^{66}$ However, in the case of the UN, there is scant evidence of the latter two components, exemplified in the persistence of unpunished sexual abuse of civilians by peacekeepers, ${ }^{67}$ despite the promulgation of a Bulletin prohibiting such by the UN Secretary General in $2003 .{ }^{68}$ An example of norm creation by the Secretary General, the failure of this Bulletin to prevent such behaviour is largely due to the immunity of peacekeepers from local jurisdiction as provided for in the SOFA, ${ }^{69}$ and the fact that disciplinary measures remain with the TCNs and not with the UN. ${ }^{70}$

\subsubsection{Command and Control}

At a more prosaic level, evidence of legal independence can be found in the structure of peacekeeping, with the UN Secretary General being the "organizer, recruiter, and director of peacekeeping operations ... together with being the nominal commander in chief of, at present, nearly 100,000 peacekeepers". ${ }^{71}$ This manifestation of the independence of the Secretary General from member states appears to imbue peacekeeping with greater autonomy than the original Charter scheme for peace enforcement contained in Chapter VII. In this

\footnotetext{
${ }^{65}$ UN Doc A/RES/71/161 (2016). See also UN Secretary General's Report, 'A New Approach to Cholera in Haiti', UN Doc A/71/260 (2016).

${ }^{66}$ O. Schachter, 'United Nations Legal Order: An Overview', in O. Schachter and C.C. Joyner (eds.), United Nations Legal Order (Cambridge, Cambridge University Press, 1996) p.1.

${ }^{67}$ A.M. Nguyen, 'Sexual Exploitation and Abuse in Peace Operations: Is the United Nations Responsible?', 19 Journal of International Peacekeeping (2015) p.142.

68 'Special measures for protection from sexual exploitation and abuse', UN Doc ST/SGB/2003/13.

69 'Model Status of Forces Agreement for Peace-Keeping Operations', UN Doc A/45/594 (1990), para.27.

${ }^{70}$ Ibid, para.47(b).

${ }^{71}$ B.E. Urquhart, 'The Evolution of the Secretary General', in S. Chesterman (ed.), Secretary or General? The UN Secretary-General in World Politics (Cambridge University Press, Cambridge, 2007) p.30.
} 
unfulfilled part of the UN Charter, the centrality of the Military Staff Committee consisting of the chiefs of staff of the five permanent members retains ultimate control of such operations with the veto-wielding states in the Security Council, ${ }^{72}$ and certainly much greater autonomy than the decentralised system of peace enforcement that has emerged, which does not exhibit legal autonomy beyond an often open-ended authorising resolution adopted under Chapter VII. While UN-authorised peace enforcement operations are "managed at the operational level by a non-UN entity such as a regional arrangement, coalition, or lead state", UN peacekeeping missions are "managed at the operational level by the UN itself (today through the Department for Peacekeeping Operations/Department of Field Support)". ${ }^{3}$

UN command and control is not complete but neither is it a chimera. ${ }^{74}$ Orders are given by the UN Force Commander to those in command of TCNs, but there is the possibility that some of the more significant ones (for example to deploy a contingent into a more dangerous area of the host country) will not be followed after the TCN commander consults with his or her government. ${ }^{75}$ There is also the lack of on-going control of specific operations once a command is given; but largely UN commands are followed and overall control is exercised by the UN over TCNs. Indeed, Johnstone has described the Secretary General's pivotal role in the chain of command as one of "norm entrepreneur", in that he must interpret the often broad terms of the mandate given by the Security Council and exercise his discretion in carrying them out. ${ }^{76}$ Johnstone gives the example of the move after 1999 towards Chapter VII mandates for peacekeeping operations in order "to protect civilians under imminent threat of physical violence", though these instructions are limited by the phrase "within the mission's capabilities and areas of deployment". ${ }^{77}$ These terms entail the delegation of "considerable discretion" to the Secretary General with, for example, robust action to protect civilians being taken by MONUC peacekeepers in the east of the DR Congo, "based on an expansive reading

\footnotetext{
72 Article 47 UN Charter 1945.

73 A.J. Bellamy and P.D. Williams, 'Trends in Peace Operations, 1947-2013', in Koops, Macqueen, Tardy and Williams, supra note 1, p.13.

${ }^{74}$ On the deepening of EU command, and its increasing autonomy from NATO structures, see T. Tardy, 'MPCC: towards an EU military command?', EUISS Brief Issue 17 (2017): https://www.iss.europa.eu/sites/default/files/EUISSFiles/Brief\%2017\%20MPCC.pdf, accessed 8 June 2018), concerning the new military planning and conduct capability (MPCC).

${ }^{75}$ R. Thakur and D. Banerjee, 'India: democratic, poor, internationalist' in C.Ku and H. Jacobson (eds.), Democratic Accountability and the Use of Force in International Law (Cambridge University Press, Cambridge, 2003) p.198.

${ }^{76}$ I. Johnstone, 'The Secretary-General as Norm Entrepreneur', in Chesterman, supra note 71, p.130.

${ }^{77}$ For example UN Doc S/RES/1299 (1990) re the DR Congo.
} 
of the mandate" including pre-emptive action against some of the armed groups on the grounds that they were a "constant threat to civilians". ${ }^{78}$

\subsection{Evidence of a Legal Regime Governing Peacekeeping}

\subsubsection{Key Principles}

From Hammarskjold to modern debates in the UN's Special Committee on Peacekeeping the emphasis has been on the trio of principles as the governing norms of peacekeeping: consent; limited use of force, and impartiality. In setting up the Congo force in 1960, in a very different situation to the creation of UNEF in Suez four years earlier, the Secretary General reported that the force (ONUC) was being sent at the request of the government of the Congo with its consent, and "although it may be considered as serving as an arm of the Government for the maintenance of order and the protection of life", the force remained under the "exclusive command of the United Nations"; it was not under orders from the host government nor would it take part in any internal conflict as that would seriously endanger the impartiality of the UN. ${ }^{79}$ As the government collapsed after two months, and secessionist forces in Katanga fought to break away from the Congo, the UN force had to become more interventionist than foreseen by the Secretary General, and indeed engaged in combat by taking offensive action against armed secessionists. ${ }^{80}$ The UN tried to maintain its impartiality by not forcing a political solution on the Congo, ${ }^{81}$ but its mandate was to maintain the Congo as a single state and this necessarily led to armed confrontation with secessionist forces.

Despite the evident flexibility within the concept of peacekeeping, allowing for very different understandings of the key principles, every year since it was established by the General Assembly as a subsidiary organ in 1965, the Special Committee on Peacekeeping Operations repeats the formula regarding the "guiding principles" of peacekeeping: strict observance of the purposes and principles of the UN Charter; "respect for the principles of the sovereignty,

\footnotetext{
${ }^{78}$ Johnstone, supra note 76, p.136.

${ }^{79}$ UN Doc S/4389 (1960) p.3.

${ }^{80}$ J. Boulden, 'United Nations Operation in the Congo (ONUC)', in Koops, Macqueen, Tardy, Williams, supra note 1, p.167. The Security Council, without invoking Chapter VII, authorised ONUC to use force - UN Doc S/RES 161 (1961); UN Doc S/RES/169 (1961).

${ }^{81}$ Boulden, supra note 80, p.167.
} 
territorial integrity and political independence of states"; "non-intervention in matters that are essentially within the national jurisdiction of any State"; as well as respect for the more specific basic principles of peacekeeping, namely "consent of the parties, impartiality and the non-use of force except in self-defence". 82

These principles are adapted from quite basic and orthodox axioms of international law: sovereignty; non-aggression and non-intervention; but have proved remarkably adaptable to the changing nature of conflict, post-conflict violence and peacekeeping, so that in the most recent UN iteration of peacekeeping doctrine (the Capstone Doctrine of 2008), force is allowed against spoilers or other non-state actors that undermine the peace. Consent is linked to a peace process or peace agreement, and impartiality is in the application of the force's mandate, not neutrality between the parties. ${ }^{83}$ It should be borne in mind that this was anticipated by the Congo force in the 1960s, when the International Court of Justice found that ONUC did not constitute enforcement action exclusively within the competence of the UN Security Council because it was based on the consent of the government and did not take military measures against any state. ${ }^{84}$ Nevertheless, the force engaged secessionists, mercenaries and other armed groups in combat.

The influence of UN doctrine on regional organisations such as the EU and AU is not simply through the UN's dominance of the field and the fact that it very often mandates regional or joint UN-regional operations, but is also due to the provisions of Chapter VIII of the UN Charter, which establish the basic legal framework for regional organisations. Article 52 states that nothing in the Charter precludes regional organisations from "dealing" with such matters of peace and security "as are appropriate for regional action", provided that "their activities are consistent with the Purposes and Principles of the United Nations". Consensual peacekeeping, based on UN principles as developed by the universal organisation outlined above, can clearly come within this provision. When it comes to enforcement action, however, Article 53(1) states that such regional action must come under the "authority" of the Security Council, requiring the "authorization" of that body. Furthermore, the application of Article 103 of the UN Charter signifies that any obligations that states have arising out of a Security Council resolution prevail over any competing treaty obligations that might arise

\footnotetext{
${ }^{82}$ Report of the Special Committee on Peacekeeping Operations, UN Doc A/72/19, paras. 24-5.

${ }^{83}$ United Nations Peacekeeping Operations: Principles and Guidelines (United Nations, New York, 2008), pp.31-40.

${ }^{84}$ Expenses case, supra note 18, p.177.
} 
from a regional mandate. Given that the UN itself has stretched the doctrine of peacekeeping closer to peace enforcement, it is arguable that regional organisations also possess the competence to authorise more coercive peacekeeping forces, as long as they confine such military action to non-state actors. ${ }^{85}$

The Capstone Doctrine marked the most recent iteration of peacekeeping doctrine and with reports by Boutros Boutros Ghali (Agenda for Peace 1992), ${ }^{86}$ and Lakdar Brahmi (Brahimi Report 2000), ${ }^{87}$ peacekeeping doctrine and principles have clearly been shaped within the UN system, not by states. This also finds more specific and detailed application in the Secretary General's Bulletins applied to peacekeeping, principally regarding the application of international humanitarian law to peacekeepers in $1999 ;^{88}$ and proscription of sexual misconduct by peacekeepers in $2003 .{ }^{89}$ Indeed, it could be argued that the lack of accountability for sexual abuse is, in part, a product of an exploitation of the autonomy of the UN by some peacekeepers, exploiting the space between ineffective TCN disciplinary systems and a non-existent UN one.

\subsubsection{Peacekeepers and the Use of Force}

One of the guiding principles worth looking at in a little more detail is the principle that peacekeepers can only use force in self-defence. The understanding of the right of selfdefence has extended unevenly over the years to cover defence of the individual peacekeepers, his comrades and his equipment, to include defence of civilians within the control of peacekeepers or within their areas of deployment, and to defence of the everwidening mandates to maintain the peace. ${ }^{90}$

\footnotetext{
${ }^{85}$ E.P.J. Myjer and N.D. White, Peace Operations Conducted by Regional Organizations and Arrangements', in T.D. Gill and D. Fleck (eds.), The Handbook of the International Law of Military Operations (Oxford University Press, Oxford, 2015) p.185; de Volder, supra note 28, pp.82-3.

${ }^{86}$ UN Doc A/47/277-S/24111 (1992), paras.46-50. See also Supplement to an Agenda for Peace, UN Doc A/50/60-S/1995/1 (1995), paras.33-46.

${ }^{87}$ Report of the Panel on United Nations Peace Operations (Brahimi Report), UN Doc A/55/305-S/2000/809 (2000), paras. 48-51.

${ }^{88}$ Observance by United Nations forces of international humanitarian law, UN Doc ST/SGB/1999/13, 6 August 1999.

${ }^{89}$ Special measures for protection from sexual exploitation and sexual abuse, UN Doc ST/SGB/2003/13.

90 N. Tsagourias, 'Consent, Neutrality/Impartiality and the Use of Force in Peacekeeping Operations: Their Constitutional Dimension', 11 Journal of Conflict and Security Law (2006) p.473.
} 
The reality, however, is that peacekeeping forces have been authorised to go beyond selfdefence when faced with hostile non-state forces. In the case of ONUC in the Congo in the 1960s, the Secretary General's initial position was that "men engaged in the operation may never take the initiative in the use of armed force, but are entitled to respond with force to an attack with arms"; "the basic element involved is clearly the prohibition against any initiative in the use of armed force". ${ }^{91}$ However, it is clear that ONUC had to take offensive action to defend the broader mandate, as have subsequent UN forces in the Congo. In the case of MONUC, deployed between 1999-2010, "the absence of a viable peace process" meant that "peacekeepers were drawn even deeper into the conflicts of eastern Congo", 92 requiring the support of short-term interventionist EU forces in 2003 and again in 2006. ${ }^{93}$ MONUC's successor (MONUSCO) was quickly engaged in "robust actions against militias in North and South Kivu", ${ }^{94}$ but its inadequacies in protecting civilians and the peace process led to the Security Council authorising the creation of an Intervention Brigade "on an exceptional basis without creating a precedent or any prejudice to the principles of peacekeeping", with an offensive mandate that included the "responsibility of neutralizing armed groups". 95 As Doss writes: "in the name of protection and stabilization, the Security Council, by authorizing UN forces to carry out, either unilaterally or jointly with the FARDC [government forces], robust, highly mobile, and versatile 'targeted offensive operations', has consciously crossed the Rubicon from peacekeeping to peace enforcement". 96

The UN's Due Diligence Policy 2013, whereby the UN accepts it has obligations to take measures to reduce the risk of human rights violations by non-UN security forces it provides support to, is a positive step in the further development of UN peacekeeping law by its acceptance of positive obligations of conduct. ${ }^{97}$ However, it is also a negative step at least in the sense that it is a recognition of the fact that UN peacekeepers in some operations, for example in the DR Congo, have fought alongside government troops in a way that states do at the invitation of a legitimate government. Instead of acting as an autonomous impartial

\footnotetext{
${ }^{91}$ UN Doc S/4389 (1960), p.5.

92 A. Doss, 'United National Organization Mission in the Democratic Republic of the Congo (MONUC)', in Koops, Macqueen, Tardy and Williams, supra note 1, p.667.

${ }^{93}$ Brosig, supra note 6.

94 A. Doss, 'United Nations Organization Stabilization Mission in the Democratic Republic of the Congo (MONUSCO)', in Koops, Macqueen, Tardy and Williams, supra note 1, p.806.

${ }^{95}$ UN Doc S/RES/2098 (2013).

${ }^{96}$ Doss, supra note 94 , p.814.

97 'Human rights due diligence policy on United Nations support to non-United Nations security forces', UN Doc A/67/775-S/2013/110 (2013).
} 
international actor between states or within states, in these instances the UN acts as a statelike autonomous actor. ${ }^{98}$

The infusion of Chapter VII elements into peacekeeping mandates has introduced the idea that the right to use lethal force is grounded in UN Law rather than in those international regimes that regulate the use of force by states - the jus ad bellum, the jus in bello, and international human rights law. Operating normally outside of an armed conflict, the trend has been to recognise that peacekeepers have a very robust right of self-defence that includes using force to protect civilians and essential property, but also to protect the mandate, meaning that peacekeeping forces should not simply respond to attacks but should be proactive and prevent them. That might lead them to engage as combatants and therefore be bound by international humanitarian law as recognised in the Secretary General's Bulletin of 1999, but even that was a form of incorporation by administrative act into UN peacekeeping law. ${ }^{99}$ When not engaged as combatants peacekeepers seem to be subject to a legal regime that is not as restricted as provided for in human rights law, which allows state agents to use potentially lethal force in self-defence when absolutely necessary in defence of themselves or others, to effect and arrest or prevent the escape of a detainee, or during action to quell a riot or insurrection. ${ }^{100}$

The UN has, in effect, shaped a new law governing the use of lethal force by peacekeepers drawing on the powers contained in Chapters VI and VII of the Charter; one that ranges from a UNEF model of passive peacekeeping with peacekeepers defending themselves from attack, to proactive protection operations with peacekeepers preventing attacks on civilians by taking initiatives in using force, to all out enforcement against non-state groups. Bearing in mind that, at the same time, UN peacekeepers when not engaged as combatants are themselves protected from attacks against them under UN Law by virtue of the 1994 UN Convention on the Safety of UN and Associated Personnel and by provisions in the Rome Statute, ${ }^{101}$ then the result is an independent armed force subject to its own legal regime separate from the national legal order of the hosts state, and increasingly autonomous from general international law.

\footnotetext{
${ }^{98}$ See also the African Union Mission in Somalia (AMISOM), supra note 30.

99 'Observance by United Nations forces of international humanitarian law', UN Doc ST/SGB/1999/13, 6 August 1999.

100 L. Doswald-Beck, Human Rights in Times of Conflict and Prevention (Oxford University Press, Oxford, 2011) p.161, drawing on section 2(2) European Convention on Human Rights 1950.

${ }^{101}$ Articles 8(2)(b)(iii), 8(2)(c)(iii) Rome Statute of the International Criminal Court 1998.
} 
That, of course, may be immediately appealing as it represents the evolution of a legal order specific to the needs and many functions of peacekeeping, but it does represent a significant legal development that largely sits somewhere between the relatively tightly restricted occasions when authorised agents can use force in peacetime (in human rights law), and the general right to use of lethal force against combatants in wartime (in international humanitarian law). This may be of greater concern when the increasing use of private security contractors by the UN is taken into account, given that UN control over such actors is largely of a contractual rather than a military nature, meaning that the application of UN peacekeeping law to these forces will be problematic. Although UN doctrine restricts such actors to specific tasks such as guarding, which will not usually expose them to military action, they remain armed personnel in hostile situations and as such there will be occasions when they use lethal force. ${ }^{102}$

\subsubsection{Peacekeeping and Peacebuilding}

The expansion of peacekeeping forces into peace operations, starting with the multidimensional force in Namibia in 1989, has increased the autonomy of such operations, with the so-called "civilianization" of peacekeeping reflecting a trend towards UN administrators exercising sovereign powers, most clearly in East Timor and Kosovo in $1999 .{ }^{103}$ Sovereign powers cannot easily be reconciled with the UN Charter. Indeed, the necessity of the UN exercising sovereign powers when necessary for the purposes of achieving peace and security without a clear prohibition on such, encapsulates the idea of inherent powers of the UN rather than powers that can be tied back to the intent of the drafters. Although peacekeepers play a vital role in these operations, the influence of TCNs has been watered down by the growth of administrators who work for the UN and not their national states. ${ }^{104}$

'Peacebuilding', defined by the UN Secretary General's Policy Committee in 2007 as a "range of measures targeted to reduce the risk of lapsing or relapsing into conflict by

\footnotetext{
${ }^{102}$ M. Sossai, 'The Privatisation of the Core Business of UN Peacekeeping Operations: Any Legal Limit?', 16 International Community Law Review (2014) p.405.

${ }_{103}$ J. Cockayne and D. Malone, 'United Nations Peace Operations: Then and Now', 9 International Peacekeeping (2005) p.18.

${ }^{104}$ Article 100(1) UN Charter 1945.
} 
strengthening national capacities at all levels for conflict management, and to lay the foundations for sustainable peace and development". ${ }^{105}$ It is a distinctly UN phenomenon, evidenced by the establishment of the Peacebuilding Commission by joint resolutions of the Security Council and General Assembly in $2005 .{ }^{106}$ It intimately involves the UN in stabilising, often reconstituting, a post-conflict state, something that cannot be entrusted to individual states. That Commission has been underpowered in practice due to the reticence of key states, but this dependency will be reduced as other UN programmes and agencies such as the World Bank, and non-state actors including foundations, charities and businesses coordinate their actions.

\section{Conclusion: Limiting Autonomy?}

Of course the direction is not all one way - towards increasing autonomy of peacekeeping law and practice. The influence of states, especially TCNs, remains strong so that sovereign concerns prevail in a number of circumstances. For instance, the availability of troops for UN peacekeeping is weighted in favour of TCNs under the existing standby agreements between the UN and states, ${ }^{107}$ referral by TCN commanders of problematic UN commands to their governments for approval or not remains endemic, and TCNs from developing countries still interpret the rules on the use of force conservatively despite what is stated in UN doctrine and in the mandate. ${ }^{108}$ Furthermore, in the case of conflicts between UN and TCN rules of engagement the latter may well prevail in practice, ${ }^{109}$ something that is primarily because military discipline remains with the TCNs and not the UN. The standard SOFA of 1990 is geared to protect the troops from local prosecution but, in so doing, it allows a huge amount of TCN discretion being exercised on the issue of accountability of peacekeepers. ${ }^{110}$ The UN seems reluctant to do anything about this by, for example, introducing fundamental human

\footnotetext{
${ }^{105}$ Available at http://www.unpbf.org/application-guidelines/what-is-peacebuilding/ (accessed 25 June 2018); R. Paris, 'Post-Conflict Peacebuilding', in T.G. Weiss and S. Daws (eds.), The Oxford Handbook on the United Nations (Oxford University Press, Oxford, 2007) pp.405-6.

${ }^{106}$ UN Doc A/RES/68/180 (2005); UN Doc S/RES/1645 (2005).

${ }^{107}$ Model SOFA, supra note 69, para.47(b).

${ }^{108}$ Thakur and Banerjee, supra note 75.

${ }^{109}$ P. Rowe, 'The United Nations Rules of Engagement and the British Soldier in Bosnia', 43 International and Comparative Law Quarterly (1994) p.946.

${ }^{110}$ Scheffer, supra note 24.
} 
rights guarantees into SOFAs or in the form of a Bulletin on Human Rights, ${ }^{111}$ given that it might impact on the availability of troops for its operations.

While the above can be represented as a ways of providing checks on the growing autonomy of the UN, they also contribute to the lack of accountability of the UN for the misconduct or lack of due diligence of its peacekeepers. The lack of accountability is also contributed to by UN immunity before national courts, ${ }^{112}$ and also because of the consolidation of the "effective control of conduct test" for attribution often giving rise to responsibility on the part of the TCN but not the UN. ${ }^{113}$ Consciously or not, by preserving a significant degree of control over their military contributions to peacekeeping, TCNs have contributed to what might be called the negative autonomy of UN peacekeeping, namely the lack of UN responsibility and accountability for the wrongful acts or omissions of peacekeepers.

There is plenty of evidence that there now exists an autonomous legal order governing peacekeeping, in which the UN is the dominant lawmaker and actor and in which specific rules, for example, on the use of force have been developed. Furthermore, there is some evidence that those rules on the use of force are not fully compatible with general international law. In addition, while the rule-making element of an autonomous legal order for peacekeeping is present, there remain serious gaps in enforcement and redress when those rules are breached.

\footnotetext{
${ }^{111}$ Recent SOFAs incorporate references to international humanitarian law treaties but not to human rights ones. See, for example, Agreement Between the United Nations and the Government of Haiti Concerning the Status of the United Nations Operation in Haiti (MINUSTAH), 9 July 2004, para. 6.

112 See discussion of UN's immunity in relation to the outbreak of cholera in Haiti in 2010 in N. Schrijver, 'Beyond Srebrenica and Haiti', 10 International Organizations Law Review (2013) p.588.

${ }^{113}$ Article 7 Articles on the Responsibility of International Organisations 2011.
} 